\title{
YHWH and Israel in terms of the Concept of Life in Deuteronomy ${ }^{1}$
}

\author{
Albert J. Coetsee (North-West University)
}

\begin{abstract}
References to the concept of "life" (the root חיה) are found throughout the book of Deuteronomy. Yet very few surveys have been done on the concept of life in Deuteronomy. This article contributes to the discussion by giving a survey of the different ways in which the concept of life is employed in the book. The results of this survey are used to give an overview of this concept from a theological point of view by determining what Deuteronomy as a whole says about YHWH and Israel in terms of the concept of life. Among others, the article finds that YHWH is depicted as the only living God, who has no end or diminishing of life. Israel is to obey YHWH's commands wholeheartedly to enjoy well-being or quality of life, which is the result of his blessing, especially in the form of prosperity, longevity and increase in the Promised Land.
\end{abstract}

KEYWORDS: Deuteronomy, life, live, living, alive, YHWH, Israel, prosperity, longevity, obedience.

\section{A INTRODUCTION}

One of the key concepts of the book of Deuteronomy, is the concept of "life". The root "live", "alive", "life") is found 39 times in the book. ${ }^{2}$ Although the root חיה is very common in the Old Testament, ${ }^{3}$ even a cursory reading of

* Submitted: 04/01/2019; peer-reviewed: 09/04/2019; accepted:16/04/2019. Albert Coetsee, "YHWH and Israel in terms of the Concept of Life in Deuteronomy," Old Testament Essays 32 no. 1 (2019): 101-126. DOI: https://doi.org/10.17159/2312-36 21/2019/v32n1a7.

1 This paper was presented at the annual meeting of the Old Testament Society of South Africa held at the North-West University in Potchefstroom 14-16 August 2018. The comments and inputs of scholars present were incorporated in the article.

2 This count is supported by G. Gerleman, "חיה," TLOT 1:413, John T. Willis, "Man Does Not Live by Bread Alone'," ResQ 16(3-4) (1973):148, and Dominik Mark1, "This Word is Your Life: The Theology of 'Life' in Deuteronomy," in Gottes Wort im Menschenwort: Festschrift für Georg Fischer SJ zum 60. Geburtstag (ÖBS 43) (ed. D. Markl, C. Paganini and S. Paganini; Frankfurt am Main: Peter Lang, 2014), 72.

3 Gerleman, TLOT 1:413 talks of "the approximately 800 occurrences of the root" in the Old Testament (his exact count is 777). H. Ringgren, "חָז chāyāh; יח chai;

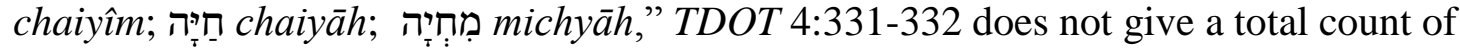
the root, but a count of the occurrence of the verb חָיזָ (224x) 
Deuteronomy leads one to the conclusion that "life" is used as a key concept in the book.

Yet very few surveys have been done on the concept of "life" in Deuteronomy. The only study on this subject in recent literature, is the work of Markl (2014). ${ }^{4}$ In a very informative article, he gives "an overview of the occurrence and distribution of the root" חיה within Deuteronomy, discusses "the most significant contexts in which" the concept appears, considers how this concept reaches a climax in Deuteronomy 30 and highlights how the concept functions within the parenetical framework of Deuteronomy. ${ }^{5}$

In this article, I wish to contribute to the discussion of the key concept of "life" (חיה) in Deuteronomy by following another route. I give an overview of this concept from a theological point of view. A quick study of the root חיה seems to indicate a striking pattern: almost all occurrences of the concept have to do with either YHWH or his people. Among others, Deuteronomy depicts YHWH as the living God $(5: 26)$, and Israel as the people who live from everything that comes from his mouth (8:3). But what does Deuteronomy as a whole say about YHWH and Israel in terms of the concept of life? This is the question that this article endeavours to answer.

In order to answer this question, the article starts by giving an overview of the occurrence and distribution of the root חיה in Deuteronomy. This is followed by a survey of the different ways in which the concept of life is employed in Deuteronomy. The results of this survey are then used to determine what Deuteronomy as a whole says about YHWH and Israel in terms of the concept of life. ${ }^{6}$

and the noun (147x). A basic word search on Logos Bible Software indicated that the root is found 806 times in the BHS.

4 Mark1, "This Word is Your Life," 71-96.

5 Markl, "This Word is Your Life," 71.

6 Since the aim of this article is to give an overview of the theme of life in Deuteronomy as a whole, it focuses on the text of Deuteronomy as a whole. While the important historical-critical research of various Old Testament scholars are noted, this article does not endeavour to reconstruct the possible underlying sources of the text of Deuteronomy. It works with the text as we have it and as it presents itself, namely as the words of Moses to the Israelites prior to their conquest of the Promised Land. Accordingly, the approach of this article is text-immanent, but not in an a-historical sense. 


\section{B THE OCCURRENCE AND DISTRIBUTION OF חיה IN DEUTERONOMY}

The 39 occurrences of the root חיה in Deuteronomy are found in the form of the

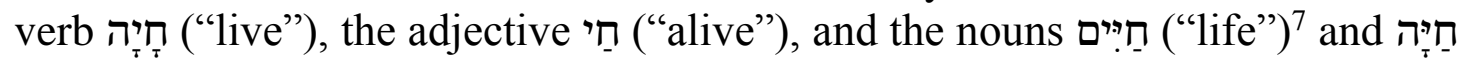
("living thing"). An overview of the occurrence of these words in Deuteronomy can be seen in Table $1 .^{8}$

\begin{tabular}{|c|c|c|}
\hline חָיזה & $18 \mathrm{x}$ & $\begin{array}{l}4: 1,33,42 ; 5: 24,26,33 ; 6: 24 ; 8: 1,3^{2} ; 16: 20 ; 19: 4,5 ; 20: 16 ; \\
30: 16,19 ; 32: 39 ; 33: 6\end{array}$ \\
\hline חַי & $8 \mathrm{x}$ & $4: 4,10 ; 5: 3,26 ; 12: 1 ; 31: 13,27 ; 32: 40$ \\
\hline חַיְים & $12 \mathrm{x}$ & $4: 9 ; 6: 2 ; 16: 3 ; 17: 19 ; 28: 66^{2} ; 30: 6,15,19^{2}, 20 ; 32: 47$ \\
\hline חָיזה & $1 \mathrm{x}$ & $7: 22$ \\
\hline
\end{tabular}

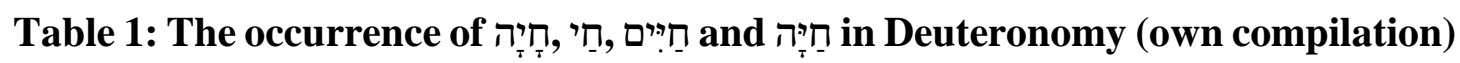

Not much can be deduced from the occurrence of the different forms of in Deuteronomy, except that the book reveals a preference for the use of the verb חָזיז ( $146 \%$ of the occurrences of the root), while the noun חַיָּ is used only once.

An investigation of the distribution of the root חיה throughout Deuteronomy may be of more value. While there are numerous ways of interpreting the structure of Deuteronomy, the book's self-description is that of words spoken by Moses. ${ }^{9}$ Deuteronomy consists of a series of three speeches by Moses on the plains of Moab prior to their entry into the Promised Land, in which Moses leads the people towards covenant renewal by means of historical and

7 The noun 1 is often difficult to distinguish from the plural of the adjective since both have the same form in Hebrew. The context is determinative for the distinction between the noun and the adjective. Gerleman, TLOT 1:412 notes that the plurale tantum חַייים is usually understood as an abstract plural (specifically a plural of duration).

8 Cf. Markl, "This Word is Your Life," 72 for a similar table.

9 This is supported by the Hebrew title for the book, namely אלה הדברים (these are the words"). Peter C. Craigie, The Book of Deuteronomy: New International Commentary on the Old Testament (Grand Rapids, Michigan: Eerdmans, 1976), 17 emphasises that Deuteronomy is "not primarily a corpus of law, nor even an historical record; it purports rather to be a record of words addressed by Moses to the Israelites" (emphasis his). 
theological reflection, the reiteration and extension of legal stipulations, and placing the people before the choice of serving YHWH.

Although there are minor differences among scholars as to how to demarcate the three speeches of Moses (i.a. the inclusion/exclusion of a narrator's framework), the simplest delineation is done according to geographical references at the beginning of each speech. This can be seen in Table 2.

\begin{tabular}{|l|l|l|}
\hline Deut 1:1-4:43 & Moses' first speech & $\begin{array}{l}\text { “beyond the Jordan" }(1: 1,5), \\
\text { "in the land of Moab" }(1: 5)\end{array}$ \\
\hline Deut 4:44-28:68 & Moses' second speech & $\begin{array}{l}\text { “in the valley opposite Beth- } \\
\text { Peor" }(4: 46)\end{array}$ \\
\hline Deut 28:69-31:29 & Moses' third speech & "in the land of Moab" $(28: 69)$ \\
\hline Deut 31:30-34:12 & Epilogue & \\
\hline
\end{tabular}

Table 2: Deuteronomy's structure according to the three speeches of Moses (own compilation)

Following this fourfold division, the distribution of the root חיה in Deuteronomy can be seen as in Table 3.

\begin{tabular}{|l|l|l|}
\hline Deut 1:1-4:43 & $6 x$ & $4: 1,4,9,10,33,42$ \\
\hline Deut 4:44-28:68 & $20 x$ & $\begin{array}{l}5: 3,24,26^{2}, 33 ; 6: 2,24 ; 7: 22 ; 8: 1,3^{2} ; 12: 1 ; 16: 3,20 ; \\
17: 19 ; 19: 4,5 ; 20: 16 ; 28: 66^{2}\end{array}$ \\
\hline Deut 28:69-31:29 & $9 \mathrm{x}$ & $30: 6,15,16,19^{3}, 20 ; 31: 13,27$ \\
\hline Deut 31:30-34:12 & $4 \mathrm{x}$ & $32: 39,40,47 ; 33: 6$ \\
\hline
\end{tabular}

Table 3: The distribution of the root חיה in Deuteronomy according to the three speeches of Moses and the epilogue (own compilation)

From this table, it is clear that the concept of "life" is found throughout Deuteronomy. Moreover, חָד חַיים divisions. Since the bulk of the book Deuteronomy is found in Moses' second speech, it comes as no surprise that the majority of references to the concept of "life" is found in Deuteronomy 4:44-28:68. However, if one employs a basic 
numeral count of references to the root חיה in Deuteronomy, chapters 4, 5 and 30 stand out. ${ }^{10}$ Each contains five or more references to the concept, as can be seen in Table 4.

\begin{tabular}{|c|c|c|}
\hline Deut 4 & $6 x$ & 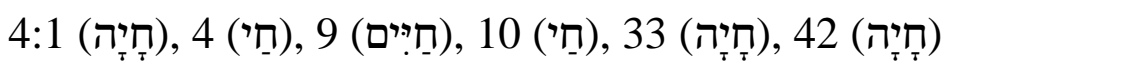 \\
\hline Deut 5 & $5 \mathrm{x}$ & 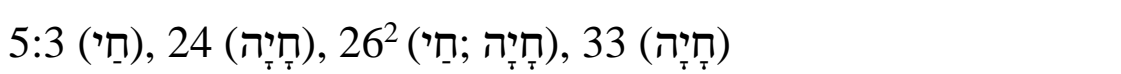 \\
\hline Deut 30 & $7 \mathrm{x}$ & 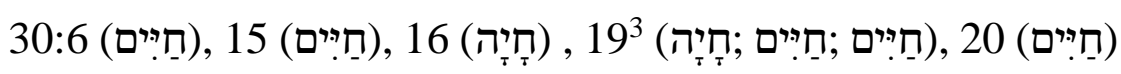 \\
\hline
\end{tabular}

Table 4: The root חיה in Deuteronomy 4, 5 and 30 (own compilation)

These clusters are striking, since Deuteronomy 4, 5 and 30 are climactic chapters in Deuteronomy:

- Deuteronomy 4:1-40 is viewed by various scholars as the climax of Moses' first speech. ${ }^{11}$ In the initial chapters of Deuteronomy (1:1-3:29), Moses gives a historical overview of the events of the past forty years, which stretches from Israel's stay at Mount Horeb to them standing on the brink of entering the Promised Land. This historical overview has the specific theological emphasis that YHWH prohibited the previous generation of entering the Promised Land because of their rebellion. The tragic fate of the previous generation is underlined in order to "emphasize to the people the importance of the present moment". ${ }^{12}$ This Moses achieves masterfully when he moves from the past to the present in Deuteronomy 4 and commands the present generation to obey YHWH. ${ }^{13}$ The exhortation to obedience is supported and strengthened by the various references to the concept of life found in the 4:1-40.

- The very next chapter, Deuteronomy 5, is one of the core chapters of the book. It forms the prologue to Deuteronomy 6:1-11:32's elaboration of the basic commandments by describing (and by implication applying) YHWH's theophany, covenant making and lawgiving at Horeb. The core of the chapter is made up of a reiteration of the Decalogue (5:6-21).

10 Markl, "This Word is Your Life," 72 finds that Deuteronomy 4, 5 and 30 contains "the highest density of the root", containing "nearly half" of the occurrences of the root. 11 Among others Christopher J.H. Wright, Deuteronomy: New International Biblical Commentary (Peabody, Massachusetts: Hendrickson Publishers, 1996), 45 and Daniel I Block, Deuteronomy: The NIV Application Commentary (Grand Rapids, Michigan: Zondervan, 2012), 114.

12 Craigie, Deuteronomy, 18.

13 The move from historical overview to direct address in 4:1 is clear from the adverb

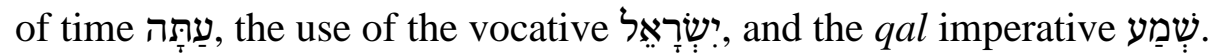


The chapter starts with the call to obey the law (5:1-5) and ends with a depiction of Moses' mediatory role at Horeb (5:22-33). While the Decalogue does not contain any reference to the concept of life, ${ }^{14}$ both the introduction to and the words following on the Decalogue do. References to the concept of life are employed to express responsibility (5:3), amazement $\left(5: 24,26^{\mathrm{b}}\right)$, YHWH's uniqueness $\left(5: 26^{\mathrm{a}}\right)$ and the need for obedience $(5: 33)$.

- As with Deuteronomy 4, a number of scholars consider Deuteronomy 30 as the climax of Moses' third speech. ${ }^{15}$ Apart from the significant reference to life in 30:6, the remaining six references to the concept of life are found in 30:15-20, where the concept is brought to a climax. ${ }^{16}$ Moses brings Israel before the choice of life or death, with obedience resulting in blessing and life, and disobedience in curse and death.

Consequently, the chapters in Deuteronomy that contain the most references to the root חיה are also the chapters that enjoy special emphasis within the book. This supports the view that חיה is a key concept of the book, and as Markl suggests, that "the concept is deliberately and systematically used". ${ }^{17}$

\section{A SURVEY OF THE EMPLOYMENT OF THE CONCEPT OF LIFE IN DEUTERONOMY}

In order to understand how the concept of life is employed in Deuteronomy, it is necessary to investigate the use, function and nuance of each of the 39 occurrences of the root חיה in the book. One possibility is to work through the text of Deuteronomy from beginning to end (i.e. starting with the first occurrence of the root חיה 4:1 and ending with the last occurrence in 33:6). However, the possibility of repetition and tedious reading suggests that another route should be followed. In what follows, the 39 occurrences of the root חיה in Deuteronomy are grouped together and discussed according to the different ways in which the book employs the concept of life. Eight such employments are identified.

\section{Life as a result of obedience}

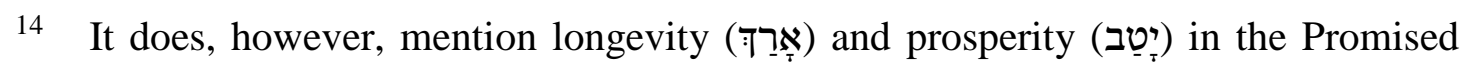
Land as the results of honouring parents (Deut 5:16).

15 Cf. Block, Deuteronomy, 694, 711. J. Gordon McConville, Deuteronomy: Apollos Old Testament Commentary (Leicester: Apollos, 2002), 423 argues that a number of factors indicates that Deuteronomy 30 is a peroration. J. Gary Millar, Now Choose Life: Theology and ethics in Deuteronomy. New Studies in Biblical Theology 6 (Leicester, Apollos, 1998), 46 views Deut 27-34 as "the climax of a carefully conceived work".

16 See especially Markl, “This Word is Your Life," 81-83. Cf. Block, Deuteronomy, 711, Wright, Deuteronomy, 291, and Walter Brueggemann, Deuteronomy: Abingdon Old Testament Commentaries (Nashville, Tennessee: Abingdon Press, 2001), 268.

17 Markl, "This Word is Your Life," 74. 
The most unique and distinguishable Deuteronomic employment of the concept of "life" is occurrences where life is described as the consequence or result of keeping YHWH's commandments. This employment of the concept of life is found eleven times in Deuteronomy $(4: 1 ; 5: 33 ; 6: 24 ; 8: 1 ; 16: 20$; $\left.30: 6,15,16,19^{3 x}\right)$.

\section{1a Deuteronomy 4:1}

The opening words of the climax of Moses' first speech start with the exhortation:

"And now, O Israel, listen to the statutes and the rules that I am teaching you, and do them, that you may live, and go in and take possession of the land that the LORD, the God of your fathers, is giving you" (Deut 4:1). ${ }^{18}$

The exhortation to "listen" (שָׁמעy) to the statutes and rules has the nuance of listening to learn and obey them, ${ }^{19}$ as underscored by the fact that Israel is explicitly commanded to "do" (עָשָׁה) them. ${ }^{20}$ This is also clear from 4:2, where the people are commanded not to add or take from the word that Moses commands them, but to "keep" (שַָׁ) the commandments (see also 4:6). This

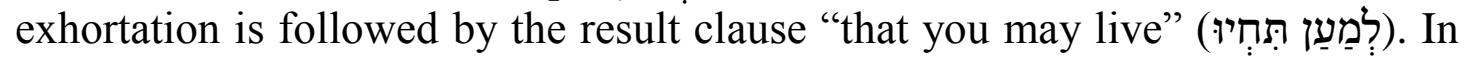
other words, the outcome of Israel's obedience is life. ${ }^{21}$

But what is the nuance of this "life"? Two interlinked answers are:

- Physical life: If Israel obeys YHWH's laws, they will remain alive. If they do not, they will die. This line of reasoning links obedience to divine sustenance and judgment.

- Israel's possession and occupation of the Promised Land: Some scholars translate $4: 1$ as "listen ... to do them, so that you may live to go in and take possession of the land". ${ }^{22}$ [My emphasis, A.C.] Understood in this way, obedience to the divine statutes and rules will allow Israel to enter

18 All English quotations from Deuteronomy are taken from the ESV. Where italics are used to emphasise certain words, they are mine.

19 K.T. Aitken, "שַַָׁ", NIDOTTE 4:177-179.

20 Cf. Millar, Now Choose Life, 48.

21 This link between obedience and life in Deuteronomy is indicated by various theological dictionaries, including Gerleman, TLOT 1:416-417 and Ringgren, TDOT 4:334-335.

22 See Moshe Weinfeld, Deuteronomy 1-11: Anchor Bible (New York, New York: Doubleday, 1991), 195, and Jeffrey H. Tigay, The JPS Torah Commentary: Deuteronomy (Philadelphia: Jewish Publication Society, 1996), 42. 
and occupy the Promised Land; disobedience will result in physical death prior to the conquest.

The former view is supported by Deuteronomy 4:4, where Moses reminds the people that those who did not follow the Baal of Peor (cf. Num 25:1-9; 31:16), but held fast to YHWH, are "alive" (חָיים) today. The idolatry of the previous generation resulted in YHWH's anger, and their physical death. The people addressed were "living proof" of the importance of obedience. ${ }^{23}$ The latter view is supported by the warning of Deuteronomy 4:26, where the people are warned that they will perish in the land if they commit idolatry, as well as the various references in Deuteronomy that makes obedience a prerequisite for possession and occupation of the land (e.g. 4:26; 5:33; 8:1; etc.).

However, the broader context of Deuteronomy 4 supports the view that more than physical life is meant in $4: 1$ :

- Deuteronomy 4:9-10 seems to imply that Israel may somewhere during their life-span forget what YHWH did for them and taught them, and yet remain alive.

- The warning of 4:26 that disobedience will make the people perish from the land "soon" and that they will "not live long in it" implies that disobedience does not necessarily result in immediate death.

- The warning against exile in 4:28 implies that disobedience would not result in everyone's death, for some would go into exile.

The rest of Israel's history recorded in the Old Testament supports this interpretation. Although some died because of their disobedience to YHWH, not everyone did. Some remained alive in the physical sense of the word. There are no traces of the application of a purely mechanical retribution principle.

Consequently, although Deuteronomy 4:1's reference to life as a result of obedience to YHWH's commandments does refer to physical life, it should be understood as more than this. "Life" in 4:1 rather seems to have the nuance of well-being or quality of life. If Israel obeys YHWH, not only will they live physically, but they will enjoy his blessing, namely the fullness of life that comes from living in relation and obedience to him. ${ }^{24}$ As will be seen in the other references to life in this category, Deuteronomy as a whole seems to support this view. This is also supported by the final words of Moses' first speech, in which

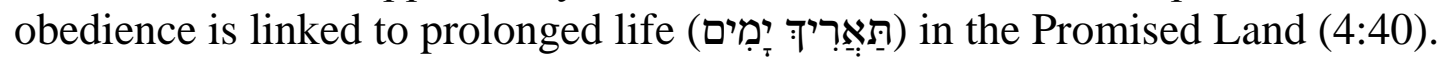

23 Daniel I. Block, "The grace of Torah: the Mosaic prescription for life (Deut 4:1-8; 6:20-25)," BSac 162 (Jan-Mar 2005):8-9.

24 Cf. Block, Deuteronomy, 115. 


\section{1b Deuteronomy 5:33}

Deuteronomy 5, which contains the Decalogue and forms the prologue to 6:111:32's elaboration of the basic commandments, concludes with these words:

"You shall walk in all the way that the LORD your God has commanded you, that you may live, and that it may go well with you, and that you may live long in the land that you shall possess" (Deut 5:33).

Together with $5: 32,{ }^{25}$ these words emphasise the need for complete obedience to YHWH's commands. The call for obedience and the reference to the Promised Land links 4:1 with 5:33. The correspondence is strengthened by the use of an almost identical Hebrew result clause, namely "that you may live"

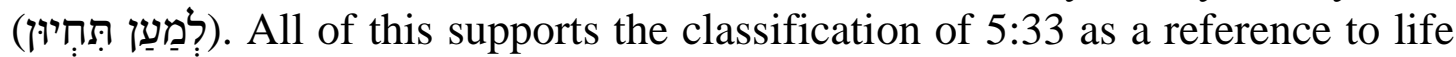
as the result of obedience.

However, more can and should be said. Deuteronomy 5:33 links life to

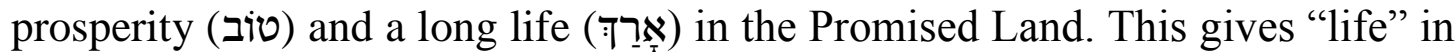
5:33 the nuance of well-being or quality of life. ${ }^{26}$ This interpretation is strengthened by 5:29, which states that obedience results in well-being (יטֵ) Once more, YHWH's blessing has obedience as a prerequisite.

\section{1c Deuteronomy 6:24}

The end of Deuteronomy 6 pictures a hypothetical situation where a son asks his father about the meaning of YHWH's commands. The prescribed answer the father is to give underscores YHWH's deliverance of Israel from Egypt with signs and wonders. The question and answer anticipates that later generations will not have a first-hand experience of the exodus and the obedience it called for. ${ }^{27}$ Among others, the father is to say:

"And the LORD commanded us to do all these statutes, to fear the LORD our God, for our good always, that he might preserve us alive, as we are this day" (Deut 6:24).

25 Eugene H. Merrill, Deuteronomy: The New American Commentary (Nashville, Tennessee: Broadman \& Holman, 1994), 160 correctly indicates that the narrative ends at 5:31, and that 5:32-33 contains exhortation.

26 This view is supported by Ringgren, TDOT 4:334. Terence E. Fretheim, "Law in the Service of Life: A Dynamic Understanding of Law in Deuteronomy," in A God so Near: Essays on Old Testament Theology in Honor of Patrick D. Miller (ed. B.A. Strawn and N.R. Bowen; Winona Lake, Indiana: Eisenbrauns, 2003), 184 refers to Deut 5:33 to substantiate his argument that "God gives the law in the service of life".

27 Block, "The Grace of Torah," 5. 
As with the references to life in Deuteronomy discussed above $(4: 1 ; 5: 33)$, life is once more linked to obedience, and the Promised Land is still in the foreground (cf. 6:23). Israel is to fear YHWH, which will result in life. However,

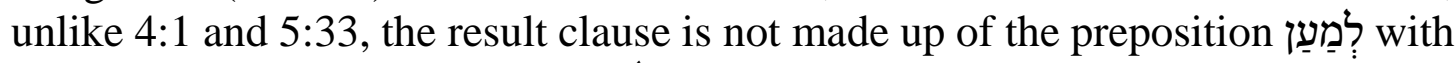

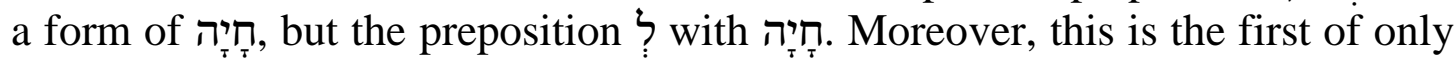
three pi 'el forms of חָיזָ in Deuteronomy (cf. 20:16; 32:39), with the pi 'el usually denoting the act of "keeping alive" 28 or "letting live". ${ }^{29}$ Block convincingly argues that obedience would result in YHWH "sustaining them alive". 30

Like 5:33, life in 6:24 is linked to well-being (טוט), which supports the interpretation of life as quality of life. ${ }^{31}$ What makes the reference to life in 6:24 unique is its link with "righteousness" (צְדָקָ) in 6:25. In this context, righteousness refers to that which is ethically right, ${ }^{32}$ namely "faithful compliance with the covenant", 33 and as such, strengthens the overall call to obedience. Obedience is viewed as the "right response" 34 to the saving acts of YHWH. ${ }^{35}$

Consequently, despite some smaller differences, "life" in 6:24 has the same nuance as in 4:1 and 5:24, namely life as the result of obedience, and life as well-being or quality of life.

\section{1d Deuteronomy 8:1}

In the midst of the basic commandments (6:1-11:32), Israel is commanded to keep YHWH's commandments in the Promised Land (8:1-20). The passage starts off with the exhortation:

"The whole commandment that I command you today you shall be careful to do, that you may live and multiply, and go in and possess the land that the LORD swore to give to your fathers" (Deut 8:1).

Again, as in the references above, life is linked to obedience $(4: 1 ; 5: 33$; 6:24) and the possession of the Promised Land (4:1; 5:33). Moreover, life as a result of obedience is once more introduced by the preposition לְ. $(4: 1 ; 5: 33)$. However, here, for the first time, life is connected to Israel's growth (רָָָ)).

\footnotetext{
28 Ringgren, TDOT 4:331.

29 Gerleman, TLOT 1:414.

30 Block, "The Grace of Torah," 17.

31 Cf. Block, "The Grace of Torah," 17, who refers to the law as "the key to a meaningful life".

32 Francis Brown, Samuel R. Driver and Charles A. Briggs, Enhanced Brown-DriverBriggs Hebrew and English Lexicon (Oxford: Clarendon Press, 1977), 842.

33 Merrill, Deuteronomy, 175.

34 Wright, Deuteronomy, 104.

35 Block, "The Grace of Torah," 13 fittingly states: "A life ordered by the stipulations of the Mosaic Covenant was to be their response to their own history".
} 
Obedience will result in the multiplication of the people. This strengthens the interpretation of חָיָָ 8:1 as well-being or quality of life. The reference to growth suggests that Israel throughout the generations is called to obedience, ${ }^{36}$ and that the possession of the land refers to its long-term retention. ${ }^{37}$

\section{1e Deuteronomy 16:20}

Deuteronomy 16:18-20 (part of the so-called "specific laws" of 12:1-26:15) contains laws regarding the appointment of judges or officers. Negatively, Israel is warned not to pervert justice (נָָטָה; 16:19). Positively, they are required to do the following:

"Justice, and only justice, you shall follow, that you may live and inherit the land that the LORD your God is giving you" (Deut 16:20).

These words state that justice (צֶדק) is a prerequisite for life in the Promised Land, with the pursuit of justice viewed as part of covenant loyalty to YHWH. ${ }^{38}$ Consequently, life is once more linked to obedience and the inheritance of the land (cf. 4:1;5:33;6:24;8:1). Syntactically, חָזָ is again introduced by the preposition לְֵֵַַ, while the previous verse $(6: 23)$ refers to the conquest and occupation of the Promised Land. All of this supports the interpretation of "life" in 16:20 as a reference to well-being or quality of life.

\section{1f Deuteronomy 30:6}

In Deuteronomy 30:1-10, part of Moses' third speech, Moses envisions a time when Israel will break the covenant stipulations, and as a result are exiled among the nations. He also envisions how they will be restored when they return to YHWH and obey him (30:1-5; cf. 4:25-31), and how YHWH will resolve his people's unfaithful inclination:

"And the LORD your God will circumcise your heart and the heart of your offspring, so that you will love the LORD your God with all your heart and with all your soul, that you may live" (Deut 30:6).

This is the second reference to the circumcision (מוֹל) of heart in Deuteronomy. The previous reference called Israel to circumcise their hearts (10:16). Here circumcision is expressed as an act of God. This striking image ${ }^{39}$ indicates that YHWH will remove whatever prevents his people from following

\footnotetext{
36 McConville, Deuteronomy, 168.

37 Brueggemann, Deuteronomy, 104.

38 Cf. Wright, Deuteronomy, 205.

39 McConville, Deuteronomy, 427 calls this circumcision " $[\mathrm{t}] \mathrm{he}$ most dramatic new thing". Craigie, Deuteronomy, 364, keeping to the imagery, refers to it as an "operation".
} 
his laws and decrees. ${ }^{40}$ They will then be able to uphold the Shema (6:4-5), namely to love YHWH with all their heart and soul. This will result in "life"; it will enable them to "live".

"Love" (אָהבב) is often used in Deuteronomy to refer to total covenant commitment. ${ }^{41}$ Consequently, as with the references discussed above, this reference to life is linked to obedience. Once more it is introduced by the proposition לִמַעַ, and once more the (return to the) Promised Land is in view. The broader context of 30:7-10 links life with prosperity (טוֹב (טר); Consequently, more than physical life is in view. "Life" in 30:6 should be understood as a reference to well-being or quality of life.

Yet, the unique emphasis of "life" in 30:6 should not be missed. The previous references emphasise obedience as prerequisite for life; here life is seen as the consequence of YHWH's gracious covenant faithfulness. ${ }^{43}$ Israel is promised that YHWH will in future enable them to do what they were supposed to do. He will enable them to obey; he will enable them to live.

\section{Deuteronomy 30:15,16,19}

As argued above, the concept of life is brought to a climax in Deuteronomy 30:15-20. ${ }^{44}$ This short passage contains six of Deuteronomy's 39 occurrences of the root חיה. ${ }^{45}$ Here Israel is given the choice between life and death, and called in the clearest words to choose life:

"See, I have set before you today life and good, death and evil. If you obey the commandments of the LORD your God that I command you today, by loving the LORD your God, by walking in his ways, and by keeping his commandments and his statutes and his rules, then you

40 Cf. Tigay, Deuteronomy, 285, and Duane L. Christensen, Deuteronomy 21:1034:12: Word Biblical Commentary (Nashville: Thomas Nelson Publishers, 2001), 739. Block, Deuteronomy, 697 states: "The metaphor refers to removing all psychological, moral, and spiritual barriers to true devotion to Yahweh, resulting in undivided love and obedience".

41 Cf. Block, Deuteronomy, 697.

42 Merrill, Deuteronomy, 389.

43 Cf. Wright, Deuteronomy, 289 and McConville, Deuteronomy, 427. The latter underscores that YHWH's grace does not abolish Israel's responsibility "to actualize their obedience".

44 Wright, Deuteronomy, 291 indicates that some even view Deut 30:15-20 as a summary of the whole book. Timothy A. Lenchak, "Choose Life!" A RhetoricalCritical Investigation of Deuteronomy 28, 69-30,20 (AnBib 129; Rome: Pontifical Biblical Institute, 1993), 113 says: "This is the high point of Moses' Third Discourse, and perhaps the high point of all Dt".

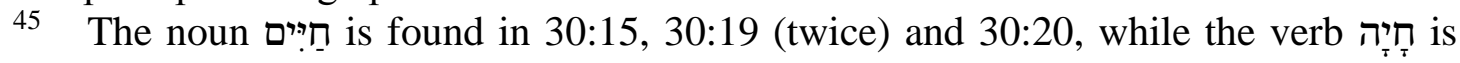
used in 30:15 and 30:19. 
shall live and multiply, and the LORD your God will bless you in the land that you are entering to take possession of it ... I call heaven and earth to witness against you today, that I have set before you life and death, blessing and curse. Therefore choose life, that you and your offspring may live ..." (Deut 30:15-16,19). ${ }^{46}$

These words form a perfect dichotomy. On the one hand, Moses links life

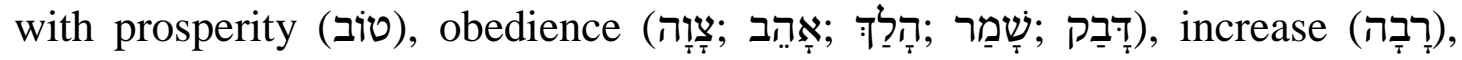
blessing (ברּרָּ]), and the entering and possession of the Promised Land. On the

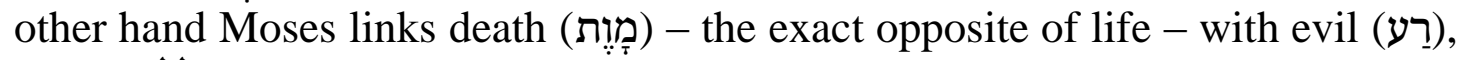
curse (קָלְלָָ), not hearing, a heart that turns away, worshipping and serving other gods, perishing, and a short life in the Promised Land (cf. 30:17-18). ${ }^{47}$ As some scholars have noted, the two choices are the equivalents of the blessings and curses described in 11:26-32 and 28:1-68. This great amplification of obedience and disobedience and its consequences is followed with the direct and urgent exhortation $^{48}$ that Israel should choose life. ${ }^{49}$ Paradoxically, according to 30:19 (once more introduced with the preposition לְמַעַ), choosing life would result in life.

Taking all of the above into account, choosing life boils down to loving YHWH wholeheartedly, ${ }^{50}$ which is to show covenant fidelity. ${ }^{51}$ Consequently, five of the six occurrences of "life" in Deuteronomy 30:15-20 refer to life as a result of obedience, and life as well-being or quality of life ${ }^{52}(30: 15,16,19) .^{53}$ The uniqueness of these references is that life is explicitly referred to as a

46 For a discussion of the awkward start of 30:16 and the text critical options, see Block, Deuteronomy, 710.

47 For an overview of the "two ways" theme in the Old Testament, see Jack R. Lundbom, Deuteronomy: A Commentary (Grand Rapids, Michigan: Eerdmans, 2013), 824.

48 The gravity of this exhortation is strengthened by the call to heaven and earth as witnesses, which is a formal element of treaties in the Near East. Cf. McConville, Deuteronomy, 430 and Christensen, Deuteronomy 21:10-34:12, 748. Moreover, although the whole Israel is addressed in these words, Moses uses the second person singular, which, according to Wright, Deuteronomy, 292 presents "the whole matter as an intensely personal choice".

49 Craigie, Deuteronomy, 366 argues that the words "are virtually a command: you shall choose life" (emphasis his).

50 Brueggemann, Deuteronomy, 270. Cf. T.L. Bersinger, “חיה", NIDOTTE 2:109.

51 Block, Deuteronomy, 711.

52 Cf. Ringgren, TDOT 4:333-335, and Merrill, Deuteronomy, 392.

53 The sixth reference to "life" in 30:15-20, namely 30:20, is discussed below (see C7). 
choice, ${ }^{54}$ albeit an obvious choice. ${ }^{55}$ The onus is on Israel to choose if they truly want to live in the Deuteronomic sense of the word. ${ }^{56}$ If they do, unlike the previous generation that chose death and destruction, they have to choose to love (obey) YHWH wholeheartedly.

\section{1h Conclusions}

In the eleven references to the concept of life discussed above, the following conclusions may be arrived at:

- All describe life as the consequence or result of obedience (covenant loyalty) to YHWH.

- All link life to the occupation and/or long-term possession of the Promised Land.

- All refer to well-being or quality of life.

- Six of these references are introduced by the preposition $8: 1 ; 16: 20 ; 30: 6,19)$.

- The most unique occurrences of this employment of the concept of life are found in 30:6 and 30:15-20.

\section{Physical life}

By far the most references to life in Deuteronomy refer to physical life. Fourteen such employments of the concept of life are found in Deuteronomy $(4: 4,33,42$; $\left.5: 3,24,26 b ; 8: 3^{\mathrm{a}} ; 19: 4,5 ; 20: 16 ; 28: 66^{\mathrm{ab}} ; 31: 27 ; 33: 6\right)$.

\section{2a Deuteronomy 4:4; 5:3}

Deuteronomy 4:4 and 5:3 overlap in the sense that both call the generation Moses

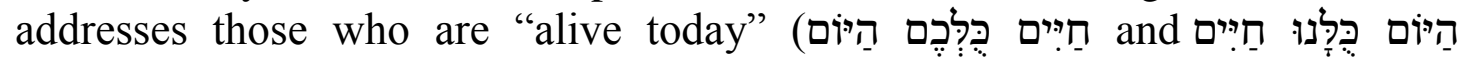
respectively). Deuteronomy 4:4 links life with obedience, referring to those who stayed true to YHWH in the midst of idolatry as those who are alive today. In an indirect manner, Deuteronomy 5:3 also links life with obedience. In the prelude

54 Patrick D. Miller, “That you may live': dimensions of law in Deuteronomy,” in Concepts of law in the sciences, legal studies, and theology (ed. M. Welker and G. Etzelmüller; Tübingen: Mohr Siebeck, 2013), 143 argues that "the kerygmatic offer of life" is "the key to" Deuteronomy as a whole.

55 Paul L. Schrieber, ““Choose Life and Not Death”: Life-and-Death Issues in Light of Deuteronomy 30:15-20”, ConJ (1998), 347 argues that the verb בָָָּ does not indicate an action of picking and choosing, but "accents the careful decision-making that is employed in determining how best to attain a certain purpose in a community (covenant) relationship".

56 Joshua brings the people before a similar choice in Josh 24:14-15. 
to the Decalogue, Moses says that YHWH made a covenant with "us", namely "all of us here alive today", the generation which is about to enter the Promised Land $(5: 2-3) .57$

\section{2b Deuteronomy 4:33; 5:24,26}

In two passages in Deuteronomy Moses calls the generation those who heard YHWH's voice and yet remained "alive" $\left(4: 33 ; 5: 24,26^{\mathrm{b}}\right)$. Both passages refer to YHWH's revelation at Horeb, aim to kindle Israel's amazement at surviving the theophany and underscore their unique experience. ${ }^{58}$ This Moses achieves with rhetorical questions in 4:33 and 5:26 ${ }^{\mathrm{b}}$, and historical reflection in 5:24. Because of Israel's fear of YHWH's revelation, they ask Moses to intercede for them in the future $(5: 27)$.

\section{2c Deuteronomy 4:42; 19:4,5}

Keeping to similar prescriptions elsewhere in the Pentateuch (cf. Num 35:9-34), Deuteronomy legislates that someone who accidentally kills his fellow-Israelite should flee to a city of refuge to save his "life" $(4: 42 ; 19: 4,5)$. The purpose was to protect the manslayer while the circumstances of the death were investigated. If accidental homicide is proven, he is given continued protection. Deuteronomy 19:5 gives an example case of accidental homicide. In all three these instances חָיזָ means "to remain alive" or "to survive". 59

\section{2d Deuteronomy 8:3}

The first part of Deuteronomy 8:3's well-known description of Israel not "living" (דָיָה ) on bread alone, refers to physical life. Moses reminds Israel that their existence does not depend on food alone. Rather, as we will see in the more indepth discussion of Deuteronomy $8: 3^{\mathrm{b}}$ below (see C6a), Israel lived from everything that came from YHWH's mouth.

\section{2e Deuteronomy 20:16}

During the conquest of the Promised Land, Israel is to vanquish (חָרֵם) their enemies completely, ensuring that nothing remains "alive" $(20: 16) .{ }^{60}$ The word חָיזָ is found in the $p i$ ' $e l$, which, like the use of the verb in 6:24 (see C1c above),

57 Moses' reference to the current generation's presence at Horeb is best interpreted as "corporate language". For good discussions on this, see Weinfeld, Deuteronomy, 238, Merrill, Deuteronomy, 142 and Lundbom, Deuteronomy, 268.

58 Cf. Block, Deuteronomy, 143-144.

59 Ringgren, TDOT 4:333.

60 The so-called law of herrem (cf. Deut $2: 34 ; 7: 1-5$ ) is one of the most difficult laws in Deuteronomy (and the Old Testament) to understand from a modern perspective. For an overview of the topic, see Lundbom, Deuteronomy, 332-334. The reason given for this harsh treatment was to prevent Israel from idolatry (20:18). 
denotes the act of "keeping alive" or "preserving alive". Literally, Israel is commanded not to "let live anything that breathes". Consequently, this employment of חָזיז refers to physical life.

Apart from the $p i^{\prime} e l$, this reference to life has other peculiarities. Markl points out that it is the only negative expression concerning life in Deuteronomy. ${ }^{61}$ Moreover, up to this point it is the only instance in Deuteronomy where life does not refer to either YHWH or Israel; it refers to the "life" of Israel's enemies.

\section{2f Deuteronomy 28:66 $6^{\text {ab }}$}

Deuteronomy 28, a whole chapter on covenant blessings for obedience and covenant curses for disobedience, concludes by warning Israel that if they do not obey YHWH wholeheartedly, they will go into exile, where their "life" will hang in suspense and they will have no assurance of their "life" (28:66 $\left.6^{\mathrm{ab}}\right)$. Because of their disobedience, YHWH will give them over to prolonged insecurity. ${ }^{62}$ The context supports the interpretation of both references to חַי physical life, ${ }^{63}$ and once more, life is linked to obedience.

\section{2g Deuteronomy 31:27}

Closer to the end of Deuteronomy, Moses reflects on the end of his life and Israel's future. He knows his death is imminent. He also knows Israel's heart, and fears that they will forsake the covenant. In 31:27 he says that they are rebellious even while he is "alive", and wonders how much more rebellious they will be after his death. ${ }^{64}$ Consequently, life in 31:27 refers to (Moses') physical life.

\section{2h Deuteronomy 33:6}

Deuteronomy 33 contains Moses' final blessing on Israel. The first tribe mentioned in his blessing is Ruben, for whom he prays that they may "live" (33:6). In this blessing, life is contrasted with death (מוּת), ${ }^{65}$ which supports the interpretation of חָזיז as physical life. Moses prays that Ruben may survive as

\footnotetext{
61 Mark1, "This Word is Your Life," 73.

62 Lundbom, Deuteronomy, 796. A number of scholars indicate that Israel's exile not only points to the reversal of blessings, but the reversal of their history. They will be deported from the very land they will conquer. See Christensen, Deuteronomy 21:10$34: 12,701$.

63 Contra Ringgren, TDOT 4:332, I do not view these references as primarily indicating life-span.

64 Tigay, Deuteronomy, 297 correctly indicates this as an a fortiori argument.

65 Ringgren, TDOT 4:332 argues that this juxtaposition most often serves for emphasis. Cf. Gerleman, TLOT 1:413.
} 
tribe. The interpretation of the second line of the blessing, however, is a matter of debate, which this study does not go into. ${ }^{66}$

\section{Life-span}

The third most common employment of the concept of "life" in Deuteronomy is the seven instances where חיה is used to refer to "life-span", namely the length of time someone lives $(4: 9,10 ; 6: 2 ; 12: 1 ; 16: 3 ; 17: 19 ; 31: 13)$.

\section{3a Deuteronomy 4:9,10; 6:2; 12:1; 31:13}

Five times in Deuteronomy Israel is called to fear or obey YHWH "all the days

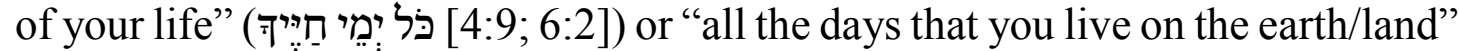

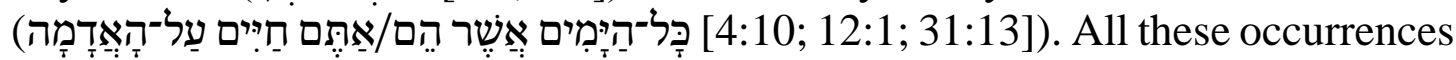
refer to Israel's life-span. ${ }^{67}$

However, lifelong obedience is not limited to the current generation. Three of these references command Israel to teach YHWH's commandments to their children $(4: 9,10 ; 31: 13)$, while one of the remaining two call on Israel to fear YHWH together with their offspring (6:2). Moreover, three of these references link lifelong obedience with the possession of the Promised Land (6:2; 12:1; 31:13), while one also links it with longevity (אָרָך), prosperity (יטֵב) and increase (רָָָָ; 6:2). Consequently, as with previous references to life in Deuteronomy, the link between life(-span) and obedience is clear.

\section{3b Deuteronomy 16:3}

In the midst of legislation on the Passover, Israel is commanded to remember the

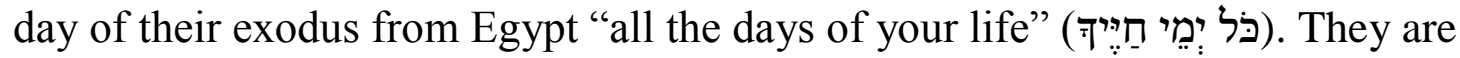
to have an annual reminder of this, and that reminder was the Passover meal. This reference links on to the similar reference to life-span and remembrance in 4:9.

\section{3c Deuteronomy 17:19}

Whereas the previous references refer to Israel's life-span, Deuteronomy 17:19 refers to the life-span of the king. The future king was to write for himself a copy

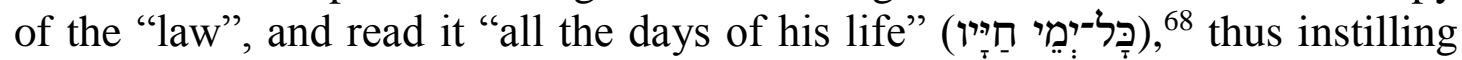
fear of YHWH and securing his prolonged reign (17:18-20). Once more the link between life(-span) and obedience is clear.

66 See McConville, Deuteronomy, 466. He indicates how ancient versions and modern translations differ whether the second line should be understood as a wish for great numbers or few.

67 Cf. Ringgren, TDOT 4:332 and Gerleman, TLOT 1:415.

68 Craigie, Deuteronomy, 257 fittingly refers to this copy of the law as the king's vade mecum, namely a guide that is constantly kept near for consultation. 


\section{The living God}

Two passages in Deuteronomy refer to YHWH as living, namely $5: 26^{\mathrm{a}}$ and 32:40.

\section{4a Deuteronomy 5:26}

In the epilogue to the Decalogue in 5:22-27, Moses reminds Israel of their reaction when they heard the words of YHWH from Horeb. They were utterly terrified, and pleaded with Moses to intercede for them in their stead in the future. At the heart of their reaction we read that they were amazed by the fact that they,

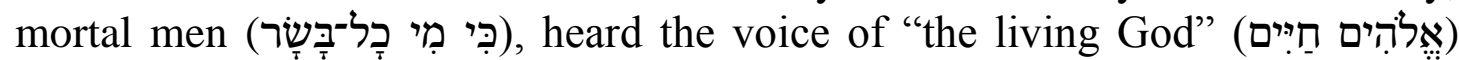
speaking out of the midst of fire, and still lived (5:26; see C2b above). ${ }^{69}$

However, there is some difference in opinion as to how the phrase "the living God" is employed in Deuteronomy 5:26. The most convincing explanations are the following:

- Some view it as a description for the being of God. He is alive; he is a living being. Moreover, he is an ever-living being (cf. 32:40), which is in direct contrast with the mortal men his theophany at Horeb was aimed at.70

- Others view the phrase as drawing a contrast between the God of Israel and the idols of the nations. He alone can act and accomplish things; they can do nothing. Ergo, he alone is the "living" God. According to Gerleman,71 the phrase "the living God" is most often used in polemical contexts, where this contrast between God and the gods is clear.72 The immediate context of Deuteronomy 5 supports this interpretation, since the end of Moses' first speech emphasises that there if no god besides YHWH $(4: 35,39)$, and the Decalogue, found just before this reference to "the living God", explicitly prohibits worshiping other gods and making idols (5:7-10).

- Still others view the phrase as describing God as being actively at work. $73 \mathrm{He}$ saved Israel from Egypt, he revealed himself to them, and

\footnotetext{
69 In the LXX and Samaritan Pentateuch, Deut 4:33 also contains a reference to the voice of the "living God". This can probably be ascribed to assimilation between 4:33 and 5:26.

70 Cf. Weinfeld, Deuteronomy, 324.

71 Gerleman, TLOT 1:416.

72 Weinfeld, Deuteronomy, 324 also mentions this contrast, indicating the difference between YHWH and "the ineffective pagan gods".

73 Cf. Ringgren, TDOT 4:339.
} 
he is on route with them to the Promised Land. He is the God who acts, who is "obviously present" with his people.74

In a way, all these explanations fit the interpretation of 5:26. Yet, the context of Deuteronomy 5 lets the scale tip slightly in favour of the interpretation that explains the phrase as making a contrast between Israel's God and the gods of the nations. Israel has experienced something that no other nation has experienced before: they heard God's voice! They heard him speak, and yet remained alive.

\section{4b Deuteronomy 32:40}

Near the end of the Song of Moses (32:1-43), in a passage that underscores that there is no god like YHWH, YHWH swears to take revenge on his adversaries and to repay those who hate him (32:39-42). His swearing is introduced in 32:40 with the act of lifting up his hand to heaven (a typical action symbolising an oath), ${ }^{75}$ followed by the oath formula "As I live forever" (חַי אָנכִי לְעוֹלָם ). Similar oath formulas are found throughout the Old Testament, ${ }^{76}$ where someone swears by YHWH, the living God. ${ }^{77}$ Here, as elsewhere in the Old Testament, YHWH swears by himself, ${ }^{78}$ implying that he acts effectually and irrevocably, ${ }^{79}$ and that "there can be no doubt about the fulfilment of his intentions". ${ }^{80}$

The secondary referent of this oath formula is of special importance for this study. YHWH is referred to as "living forever". Not only does he have power over life and death (32:39; see C8 below), but he himself lives forever. ${ }^{81}$ There is no end to or diminishing of his life.

\section{Wild animals $(7: 22)$}

While the noun חַיזָ is used in various places in the Old Testament to refer to "living things" or "animals", ${ }^{82}$ it is found only once in Deuteronomy. In the midst of Deuteronomy 7, a chapter which elaborates on Israel's mandate in warfare (especially so-called law of hẹerem), their election and YHWH's covenant

74 Ringgren, TDOT 4:339.

75 Block, Deuteronomy, 766 calls this a "dramatic non-verbal gesture".

76 For oath swearing in the Old Testament, see Manfred R. Lehmann, "Biblical Oaths," ZAW 81 (1969):74-92, and Moshe Greenberg, "The Hebrew Oath Particle Hay/He, , JBL 76(1) (1957):34-39.

77 Ringgren, TDOT 4:340 counts 43 references to the "living God" in oath formulas in the Old Testament.

78 Gerleman, TLOT 1:415 counts 23 references to divine self-declaration ("as surely as I live") in the Old Testament.

79 Ringgren, TDOT 4:340.

80 Merrill, Deuteronomy, 424.

81 Cf. Lundbom, Deuteronomy, 901.

82 Cf. Ringgren, TDOT 4:342 and Gerleman, TLOT 1:412, 415. 
faithfulness, Israel is warned not to clear away the nations in the Promised Land

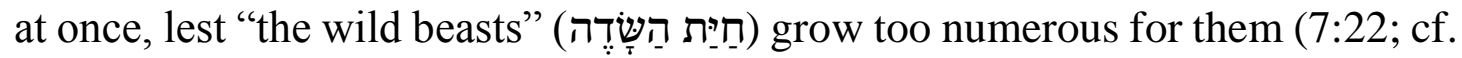
Ex 23:29). Israel is warned that a too rapid conquest will result in a resurgence of wild animals. ${ }^{83}$

This is the only instance in Deuteronomy where the root חיה is not used to refer either to YHWH or human beings, and up to this point only the second instance where it does not refer to either YHWH or Israel (see C2e above).

\section{YHWH's revealed will as source of life}

Two passages in Deuteronomy refer to YHWH's revealed will as source of life, namely $8: 3^{\mathrm{b}}$ and $32: 47$.

\section{6a Deuteronomy 8:3}

In Deuteronomy 8:1-10, in the midst of the basic commandments (6:1-11:32), Israel is commanded to keep YHWH's commandments in the Promised Land. In order to foster obedience, they are commanded to remember their experiences in the wilderness. The forty years in the desert is described as a humbling by and test of YHWH, determining whether they would keep his commandments. In a rhetorical flourish, YHWH is said to have fed them with manna (cf. Exod 16:130; Num 11:4-9):

"that he might make you know that man does not live by bread alone, but man lives by every word that comes from the mouth of the LORD" (Deut 8:3).

The parallel of these two lines is striking in Hebrew:

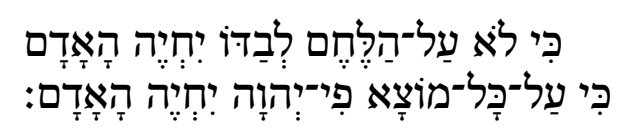

Above I argued that "live" in the first part of the parallel refers to physical life (see C2d). Here I contend that the second reference refers to YHWH's revealed will as source of life.

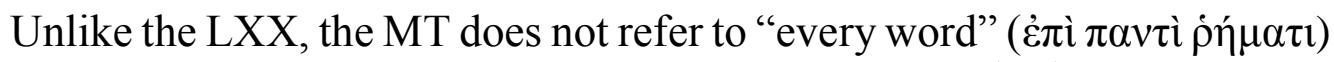

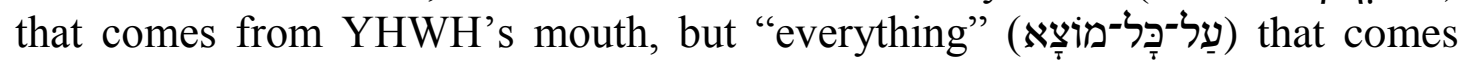
from his mouth. From the immediate context, the primary reference is YHWH's commandments (see 8:1), although it probably includes his revealed will in general ${ }^{84}$ At first glance it seems like 8:3 makes a contrast between physical and

83 Duane L. Christensen, Deuteronomy 1:1-21:9: Word Biblical Commentary (Nashville: Thomas Nelson Publishers, 2001), 165.

84 Cf. Block, Deuteronomy, 229. For a discussion of the wordplay of "everything that comes from" YHWH's mouth in Deut 8, see Raymond C. van Leeuwen, "What Comes out of God's Mouth: Theological Wordplay in Deuteronomy 8," CBQ 47 (1985):55-57. 
spiritual food. Spiritual nourishment received through YHWH's revelation is not only necessary for life along with physical food; it is more important than physical food. While there seems to be some truth in this, Willis convincingly argues that the contrast is not between physical and spiritual bread, but "bread alone" and "everything that proceeds out of the mouth of the Lord" (emphasis his). ${ }^{85}$ Manna is but one thing that comes from the mouth of God. With his revealed will YHWH gives to Israel everything they need to live, namely to obey him and consequently receive his blessing. Everything that proceeds from YHWH's mouth is "life-sustaining", ${ }^{86}$

Although all of Israel were physically fed with manna, the vast majority died in the wilderness due to their unwillingness to submit obediently to YHWH's words. In a sense, the manna in the wilderness teaches that Israel was able to live physically (at least for a while) without truly living in the Deuteronomic sense of the word, namely living in covenant relationship with YHWH by obeying his commandments and statutes, resulting in his blessing (life). ${ }^{87}$

\section{6b Deuteronomy 32:47}

Following the recital of the Song of Moses, Moses exhorts the people to be very

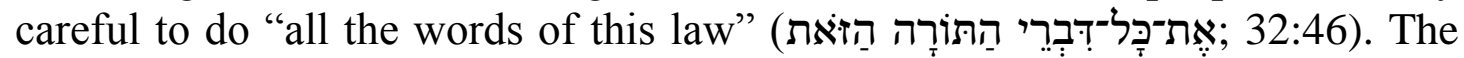
immediate reference of this phrase is the words of the Song (32:1-43). However, the ambiguity is probably deliberate to include the words of Deuteronomy in general.

The function and character of these words are described in the very next verse (32:47), where the words of the law are called "no empty word for you, but your very life". The words of the law are words spoken by God himself, with the purpose of "imparting life" 88 or leading to life. ${ }^{89}$ The rest of 32:47 speaks of longevity (אָרָך) in the Promised Land. Not only does this link closely to the employment of the concept of life in $8: 3$, but also with the constant Deuteronomic employment of life as well-being or quality of life as a result of obedience. By this word, namely by obeying YHWH's revealed will, Israel will enjoy his blessing and live long in Promised Land.

85 Willis, “Man Does Not Live by Bread Alone", 144.

86 Lundbom, Deuteronomy, 349-350.

87 Cf. Wright, Deuteronomy, 123-124.

88 Craigie, Deuteronomy, 390.

89 Merrill, Deuteronomy, 428. 


\section{YHWH and obedience as source of life (30:20)}

In the closing section of Deuteronomy (30:15-20) Israel is confronted with a choice between life and death (see $\mathrm{Clg}$ above). In this section YHWH is described as Israel's "life":

"[Therefore choose life, that you and your offspring may live,] loving the LORD your God, obeying his voice and holding fast to him, for he is your life and length of days, that you may dwell in the land that the LORD swore to your fathers, to Abraham, to Isaac, and to Jacob, to give them" (Deut 30:20).

Taking the immediate context into consideration, the phrase seems to refer to YHWH as the source and sustainer of Israel's life. However, the matter is not as simple as that. The MT says that "he/it" (הוּא) is your life, which can either be understood as YHWH ("he") or the actions of loving, obeying and holding fast to YHWH ("it"). The latter links on to the employment of life as the result of obedience. ${ }^{90}$ Exegetically, both interpretations are valid, and throughout the history of interpretation, scholars have chosen one or the other. ${ }^{91}$ Markl, who gives a thorough overview of both options, ${ }^{92}$ suggests that "the author(s) deliberately chose a form with ambiguous reference". ${ }^{93}$ If this is the case, which it seems to be, the current reference should be understood as referring to YHWH and obedience as source of life, and consequently be classified as a unique employment of the concept of life in Deuteronomy.

\section{YHWH has power over life (32:39)}

The remaining employment of חיה in Deuteronomy is found near the end of the Song of Moses (32:1-43). Written in the first person (and with the use of emphatic pronouns), YHWH proclaims that there is no god like him, and he swears to take vengeance on his adversaries (32:39-42; see $\mathrm{C} 4 \mathrm{~b}$ above). In what various scholars view as the climax of the song, ${ }^{94}$ YHWH calls himself the God

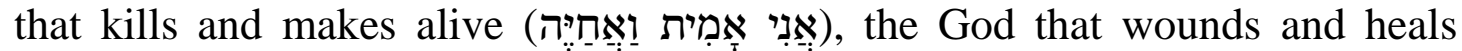
(32:39). As with previous pi el forms of the verb חיה in Deuteronomy (6:24; 20:16), the verb is interpreted as referring to the act of "keeping alive", and in this case, "making alive". ${ }^{95}$ The reference emphasises the uniqueness, power,

\footnotetext{
90 This interpretation is supported by the LXX (

91 Wright, Deuteronomy, 292 and Merrill, Deuteronomy, 394, for example, choose YHWH as the referent of הוּא , while Craigie, Deuteronomy, 366 chooses the actions of loving, obeying and holding fast to YHWH.

92 Mark1, "This Word is Your Life," 83-86.

93 Mark1, "This Word is Your Life," 86.

94 Cf. Wright, Deuteronomy, 303 and Block, Deuteronomy, 765.

95 Ringgren, TDOT 4:331, 337-338.
} 
authority and efficacy of YHWH. He is sui generis $;{ }^{96}$ he is the Lord of life and death (cf. 1 Sam 2:6; 2 Kgs 5:7); he has power over life. ${ }^{97}$ Consequently, Israel should obey him. ${ }^{98}$

Except for the striking content, this reference to the concept of life is unique in the sense that it is the only form of the verb "live" in the first person in Deuteronomy. ${ }^{99}$

\section{Summary}

The eight different ways in which חיה is employed in Deuteronomy, as well as the distribution of these references in Deuteronomy, can be seen in Table 5.

\begin{tabular}{|l|l|l|l|}
\hline 1 & Life as a result of obedience & $11 \mathrm{x}$ & $\begin{array}{l}4: 1 ; 5: 33 ; 6: 24 ; 8: 1 ; 16: 20 ; 30: 6,15, \\
16,19^{\mathrm{abc}}\end{array}$ \\
\hline 2 & Physical life & $14 \mathrm{x}$ & $\begin{array}{l}4: 4,33,42 ; 5: 3,24,26^{\mathrm{b}} ; 8: 3^{\mathrm{a}} ; 19: 4,5 ; \\
20: 16 ; 28: 66^{\mathrm{ab}} ; 31: 27 ; 33: 6\end{array}$ \\
\hline 3 & $\begin{array}{l}\text { Life-span } \\
4\end{array}$ & $7 \mathrm{x}$ & $4: 9,10 ; 6: 2 ; 12: 1 ; 16: 3 ; 17: 19 ; 31: 13$ \\
\hline 5 & $\begin{array}{l}\text { The living God } \\
\text { Wild animals }\end{array}$ & $2 \mathrm{x}$ & $5: 26^{\mathrm{a}} ; 32: 40$ \\
\hline 6 & $\begin{array}{l}\text { YHWH's revealed will as } \\
\text { source of life }\end{array}$ & $2 \mathrm{x}$ & $8: 3^{\mathrm{b}} ; 32: 47$ \\
\hline 7 & $\begin{array}{l}\text { YHWH and obedience as } \\
\text { source of life }\end{array}$ & $1 \mathrm{x}$ & $30: 20$ \\
\hline 8 & $\begin{array}{l}\text { YHWH has power over life } \\
\text { Y }\end{array}$ & $1 \mathrm{x}$ & $32: 39$ \\
\hline
\end{tabular}

Table 5: The eight different ways in which חיה is employed in Deuteronomy, and its distribution in the book (own compilation)

96 Cf. Block, Deuteronomy, 766 and L. Juliana M. Claassens, "'I kill and I Give Life': Contrasting depictions for God in Deuteronomy 32." OTE 18(1) (2005):43.

97 Cf. Bersinger, NIDOTTE 2:109.

98 Claassens, "I kill and I Give Life," 42.

99 Mark1, "This Word is Your Life," 73. 


\section{YHWH AND ISRAEL IN TERMS OF THE CONCEPT OF LIFE IN DEUTERONOMY}

The results of the survey of the different ways in which the concept of life is employed in Deuteronomy can now be used to determine what Deuteronomy as a whole says about YHWH and Israel in terms of the concept of life.

Of the 39 occurrences of the root חיה Deuteronomy, only two do not refer to either YHWH or Israel. The first is חַיזָ in $7: 22$, which refers to the "wild animals" that may grow too numerous for Israel if they clear away the nations too quickly from the Promised Land during the conquest. The second is 20:16, which refers to the physical life of Israel's enemies, who they are to devote to complete destruction ensuring that nothing remains "alive". This means that 37 of the 39 occurrences of חיה in Deuteronomy ( $\pm 95 \%)$ refer either to YHWH or Israel.

Granted that YHWH and Israel are intricately intertwined in terms of Deuteronomy's concept of life, the remaining 37 occurrences of חיה in Deuteronomy say the following about both:

\section{YHWH in terms of Deuteronomy's concept of life}

YHWH is depicted in Deuteronomy as the only living God (5:26 $)$, who has no end or diminishing of life (32:40). He has power over life and death (32:39). He is the source of his people's life (30:20), while his revealed will sustains their life $\left(8: 3^{\text {b }} ; 30: 20 ; 32: 47\right)$. He promises to one day enable his people to (truly) live by removing whatever prevents them from following his laws and decrees $(30: 6) .{ }^{100}$

\section{Israel in terms of Deuteronomy's concept of life}

Deuteronomy contains a number of references to Israel's physical life: the generation Moses addresses is called those who are "alive today" $(4: 4 ; 5: 3)$, who heard YHWH's voice at Horeb and yet remained "alive" (4:33; 5:24,26 $)$; someone who accidentally kills his fellow-Israelite can flee to a city of refuge to save his life (4:42; 19:4,5); Moses refers to himself as alive (31:27), and prays that Ruben may survive as tribe (33:6).

However, the majority of references refer to more than physical life; they refer to Israel's well-being or quality of life. Israel does not live by bread alone, but by everything that comes from YHWH's mouth (8:3). They are to obey YHWH's commandments wholeheartedly to enjoy quality of life, which is the result of his blessing, especially in the form of prosperity, longevity and increase in the Promised Land $(4: 1 ; 5: 33 ; 6: 24 ; 8: 1 ; 16: 20)$. The obedience they are called

100 Except for $5: 26^{\mathrm{a}}$ and $8: 3^{\mathrm{b}}$, it is striking that the majority of references to חיה that refer to YHWH are found in the final chapters of Deuteronomy. 
to is not fleeting or whimsical, but life-long and generation-spanning $(4: 9,10$; $6: 2 ; 31: 13$; cf. 12:1; 16:3). ${ }^{101}$ The king, as head of Israel, is to learn and exemplify wholehearted obedience to YHWH by reading from his copy of the law all the days of his life (17:19). If they do not obey YHWH wholeheartedly, they will go into exile where they will have no assurance of their life $\left(28: 66^{\mathrm{ab}}\right)$. The only sensible route to follow - in fact, the only route there is - is to deliberately choose wholehearted obedience to YHWH $\left(30: 15,16,19^{\mathrm{abc}}\right)$.

\section{BIBLIOGRAPHY}

Block, Daniel I. "The grace of Torah: the Mosaic prescription for life (Deut 4:1-8; 6:2025).” BSac 162 (Jan-Mar 2005):3-22.

Block, Daniel I. Deuteronomy: The NIV Application Commentary. Grand Rapids, Michigan: Zondervan, 2012.

Botterweck, G. Johannes \& Ringgren, Helmer, eds. Theological Dictionary of the Old Testament. 15 Vols. Translated by John T. Willis. Grand Rapids, Michigan: Eerdmans. 1975-2015.

Brown, Francis, Driver, Samuel R. \& Briggs, Charles A. Enhanced Brown-DriverBriggs Hebrew and English Lexicon. Oxford: Clarendon Press. 1977.

Brueggemann, Walter. Deuteronomy: Abingdon Old Testament Commentaries. Nashville, Tennessee: Abingdon Press, 2001.

Christensen, Duane L. Deuteronomy 1:1-21:9: Word Biblical Commentary. Nashville: Thomas Nelson Publishers, 2001.

Christensen, Duane L. Deuteronomy 21:10-34:12: Word Biblical Commentary. Nashville: Thomas Nelson Publishers, 2001.

Claassens, L. Juliana M. "'I kill and I Give Life': Contrasting depictions for God in Deuteronomy 32." OTE 18(1) (2005):35-46.

Craigie, Peter C. The Book of Deuteronomy: New International Commentary on the Old Testament. Grand Rapids, Michigan: Eerdmans, 1976.

Fretheim, Terence E. "Law in the Service of Life: A Dynamic Understanding of Law in Deuteronomy," in A God so Near: Essays on Old Testament Theology in Honor of Patrick D. Miller (ed. B.A. Strawn and N.R. Bowen; Winona Lake, Indiana: Eisenbrauns, 2003), 183-200.

Greenberg, Moshe. “The Hebrew Oath Particle Hay/Hē.” JBL 76(1) (1957):34-39.

Jenni, Ernst \& Westermann, Claus, eds. Theological Lexicon of the Old Testament. 3 Vols. Translated by Mark E. Biddle. Peabody, Massachusetts: Hendrickson Publishers. 1997.

Lehmann, Manfred R. "Biblical Oaths.” ZAW 81 (1969):74-92.

Lenchak, Timothy A. "Choose Life!" A Rhetorical-Critical Investigation of Deuteronomy 28, 69-30, 20. AnBib 129. Rome: Pontifical Biblical Institute, 1993.

Lundbom, Jack R. Deuteronomy: A Commentary. Grand Rapids, Michigan: Eerdmans, 2013.

101 Cf. Millar, Now Choose Life, 98. 
Markl, Dominik, "This Word is Your Life: The Theology of 'Life' in Deuteronomy." Pages 71-96 in Gottes Wort im Menschenwort: Festschrift für Georg Fischer SJ zum 60. Geburtstag (ÖBS 43). Edited by D. Markl, C. Paganini and S. Paganini, Frankfurt am Main: Peter Lang, 2014. https://doi.org/10.3726/978-3-653-031287.

McConville, J. Gordon. Deuteronomy: Apollos Old Testament Commentary. Leicester: Apollos, 2002.

Merrill, Eugene H. Deuteronomy: The New American Commentary. Nashville, Tennessee: Broadman \& Holman, 1994.

Millar, J. Gary. Now Choose Life: Theology and ethics in Deuteronomy. New Studies in Biblical Theology 6. Leicester, Apollos, 1998.

Miller, Patrick D. “"That you may live': dimensions of law in Deuteronomy," in Concepts of law in the sciences, legal studies, and theology (ed. M. Welker and G. Etzelmüller; Tübingen: Mohr Siebeck, 2013), 137-157.

Schrieber, Paul L. "“Choose Life and Not Death": Life-and-Death Issues in Light of Deuteronomy 30:15-20", ConJ (1998):346-356.

Tigay, Jeffrey H. The JPS Torah Commentary: Deuteronomy. Philadelphia: Jewish Publication Society, 1996.

VanGemeren, Willem A., ed. New International Dictionary of Old Testament Theology \& Exegesis. 5 Vols. Grand Rapids: Zondervan. 1997.

Van Leeuwen, Raymond C. "What Comes out of God's Mouth: Theological Wordplay in Deuteronomy 8." CBQ 47 (1985):55-57.

Weinfeld, Moshe. Deuteronomy 1-11: Anchor Bible. New York: Doubleday, 1991.

Willis, John T. “'Man Does Not Live by Bread Alone'.” ResQ 16(3-4) (1973):141-149.

Wright, Christopher J.H. Deuteronomy: New International Biblical Commentary. Peabody, Massachusetts: Hendrickson Publishers, 1996.

Dr Albert Coetsee, School for Christian Ministry and Leadership, North-West University. Email: albert.coetsee@nwu.ac.za. ORCID: https://orcid.org/00000002-5549-2474. 